\title{
TUMOR NEUROENDOKRIN: KASUS SERIAL DI RSUD DR. SOETOMO
}

\author{
Made Mahayasa $^{1}$, Paulus Soetamto Wibowo ${ }^{2}$ \\ ${ }^{1}$ Trainee Divisi Bedah Digestif, Departemen Ilmu Bedah, Fakultas Kedokteran Universitas Airlangga, RSUD \\ Dr. Soetomo, Surabaya, Indonesia. Korespondensi: mademahayasa@ gmail.com. \\ ${ }^{2}$ Divisi Bedah Digestif, Departemen Ilmu Bedah, Fakultas Kedokteran Universitas Airlangga, RSUD Dr. \\ Soetomo, Surabaya, Indonesia.
}

\begin{abstract}
ABSTRAK
Latar belakang: tumor neuroendokrin (NETs) adalah neoplasma yang dapat mensekresi hormon dengan sindrom klinis yang bervariasi. Meskipun insidennya relatif rendah, NETs merupakan tantangan klinis karena presentasi klinis yang bervariasi dan tidak ada modalitas pencitraan awal yang dapat efektif. Kasus: didapatkan 5 kasus tumor neuroendokrin selama kurun waktu 2 tahun (20082010). Hampir sebagian besar pasien yaitu $80 \%$ mengeluh nyeri abdomen dan 1 orang pasien (20\%) dengan keluhan sulit defekasi. Dari pemeriksaan pencitraan awal, ditunjukkan bahwa terdapat 2 subjek dengan asal tumor dari pankreas, 1 dari paraaorta kiri, 1 dari supra-renalis, dan 1 dari presakral. Pemeriksaan jaringan tumor melalui FNAB (fine needle aspiration biopsy) mengonfirmasi adanya Malignant Neuroendocrine Tumor pada semua pasien. Pada pemeriksaan penanda jaringan intraseluler semua menunjukkan peningkatan NSE yaitu berkisar dari 30,9-218,40 ng/ml. Dari penilaian resektabilitas tumor didapatkan 1 orang resektabel, 3 orang non-resektabel, dan 1 orang lagi menolak tindakan. Pada sebuah kasus dilakukan reseksi luas, yaitu tumor neuroendokrin pre-sakral yang sudah infiltrasi ke os sakrum (S3-4). Selama follow up paska operasi pasien ini didapatkan metastasis pada hepar dan meninggal 2 tahun kemudian. Simpulan: tumor neuroendokrin adalah bentuk neoplasma yang jarang dan muncul dengan berbagai variasi klinis. Penegakan diagnosis jaringan dapat dilakukan dengan FNAB guiding USG (ultrasonografi) atau CT dan pemeriksaan penanda jaringan NSE. Penentuan resektabilitas tumor dapat dilakukan dengan pemeriksaan CT, MSCT (multislice computed tomography) atau MRI (magnetic resonance imaging. Kesulitan dalam hal tindakan dan mortalitas yang tinggi disebabkan karena hampir sebagian besar pasien datang dalam keadaan tumor yang sudah lanjut.
\end{abstract}

Kata Kunci: tumor neuroendokrin (NETs), neoplasma, malignant.

\section{NEUROENDOCRINE TUMOR: SERIAL CASES AT DR. SOETOMO HOSPITAL}

\author{
Made Mahayasa $^{1}$, Paulus Soetamto Wibowo ${ }^{2}$ \\ ${ }^{1}$ Trainee of Division of Digestive Surgery, Department of Surgery, Faculty of Medicine Airlangga University, \\ Dr. Soetomo Hospital, Surabaya, Indonesia. Correspondence: mademahayasa@ gmail.com. \\ ${ }^{2}$ Division of Digestive Surgery, Department of Surgery, Faculty of Medicine Airlangga University, Dr. Soetomo \\ Hospital, Surabaya, Indonesia.
}

\begin{abstract}
Introduction: neuroendocrine tumors (NETs) are a rare neoplasm that can secrete hormones with varying clinical syndromes. Although the incidence is relatively low, NETs represent a significant clinical challenge because they have varied presentations and early imaging to find the tumor may become inconclusive. Case: 5 cases of neuroendokrine tumor were obtained during the period of 2 years (2008-2010). Almost the majority of patients are $80 \%$ complaining of abdominal pain and 1 patient (20\%) with difficult defecation complaints. From the initial imaging examination, 2 pancreatic origin of the pancreas was obtained, 1 of the left aorta, 1 of the supra-renalis, and 1 of the pre-sacral. Tissue diagnosis in CT guided FNAB confirmed the finding of Malignant Neuroendocrine Tumors in
\end{abstract}


all patients. All showed an increase in NSE which ranged from 30.9-218.40 ng/ml. From the assessment of tumor resectability, 1 person was resectable, 3 non-resectable, and 1 person rejected the action. In the patient with the pre-sacral neuroendocrine tumor that has infiltrated into os sacrum (S34), wide resection was performed. During postoperative follow up, this patient developed liver metastases and passed away two years after surgery. Conclusions: neuroendocrine tumors are rare form of neoplasms with varying clinical variations. Diagnosis can be done with USG or CT guided FNAB and examination of NSE marker. Determination of tumor resectability can be done by CT, MSCT or MRI examination. Almost all patients presented in advanced stage caused the difficulty of surgery and high mortality.

Keywords: neuroendocrine tumor (NETs), neoplasm, malignant.

\section{PENDAHULUAN}

Tumor neuroendokrin (NETs) merupakan sekelompok tumor yang sangat jarang terjadi dan bersifat heterogen. NETs dicirikan secara histologi oleh adanya penanda intraselular jaringan endokrin, seperti chromogranin A, synaptophysin, dan neuron spesific enolase (NSE), yang dapat digunakan dalam menegakkan diagnosis tumor ini. Dapat terjadi diseluruh bagian tubuh, namun terbanyak pada saluran cerna yang sering dikenal sebagai tumor karsinoid. Istilah carcinoid (dari Bahasa Jerman Karzinoide) telah diperkenalkan sejak tahun 1907 oleh Oberndorfer sebagai identifikasi terhadap sejumlah tumor ileum, yang berasal dari sel-sel enterochromaffin (EC) yang menghasilkan serotonin, jenis ini dicirikan dengan prognosisnya yang lebih baik dari adenokarsinoma. Penanda tumor yang paling sering digunakan adalah penanda umum NE (berlaku untuk semua sel NE), baik dalam sitosol seperti NSE dan produk gen protein 9,5 atau marker granulasi seperti chromogranin A (CGA), dan synaptophysin. Sel-sel NETs yang memerlukan immunohistochemistry hormon NETs yang dapat menimbulkan sindrom hyperfunctional didefinisikan sebagai functional NETs, sedangkan NETs yang menunjukkan immunopositivity untuk marker endokrin dan atau marker serum tetapi tidak menimbulkan sindrom klinis disebut nonfunctioning NETs. Dewasa ini WHO telah mengeluarkan klasifikasi terhadap jenis-jenis tumor ini, berlaku untuk semua NETs, ${ }^{1-6}$ yaitu welldifferentiated endocrine tumor (benign or low grade malignant), well-differentiated endocrine carcinoma, poorly differentiated endocrine carcinoma (small cell carcinoma), dan mixed exocrine-endocrine carcinoma.

Insiden NETs adalah 2 kasus per 100.000 orang dan berkisar $0,5 \%$ dari seluruh keganasan. Meskipun NETs kebanyakan ditemukan dalam saluran cerna, karsinoid dan NETs lainnya didapatkan hanya $1,5 \%$ dan $0,3 \%$ dari seluruh kanker saluran cerna di Amerika Serikat. NETs jarang ditemukan pada anak-anak dan umumnya sering terjadi pada penderita dengan usia lebih dari 50 tahun. Kejadiannya dua kali lebih banyak pada laki-laki dibandingkan perempuan. Insiden NETs tampaknya telah meningkat dalam beberapa dekade terakhir, meskipun hal ini lebih mungkin karena hasil deteksi yang meningkat dengan modalitas semakin canggih, seperti endoskopi, computed tomography (CT), magnetic resonance imaging (MRI), ultrasonografi, dan skintigrafi. $^{7-9}$ Di Jepang pada tahun 2005 
pernah dilakukan penelitian epidemiologi tentang tumor ini dan mendapatkan insiden pancreatic endocrine neoplasms (PETs) sekitar 1,01 per 100,000 dan insiden gastrointestinal neuroendocrine tumors (GI-NETs) sebesar 2,10 per 100,000. Di Indonesia, belum didapatkan data yang akurat mengenai tumor ini. ${ }^{10}$

Karena kurangnya publikasi tentang penyakit ini di Indonesia, pengalaman penanganan secara pembedahan sangat kurang. Pada artikel ini akan kami laporkan 5 kasus Tumor Neuroendokrin yang kami temukan di RSUD Dr. Soetomo selama kurun waktu 2 tahun (2008-2010).

\section{KASUS SERIAL}

\section{Kasus 1}

Laki-laki 65 tahun dengan keluhan nyeri abdomen kanan atas. Dari pemeriksaan USG dan CT-scan abdomen dengan kontras didapatkan gambaran tumor suprarenalis kanan dengan metastase hepar (gambar 1). Rontgen thoraks dalam batas normal. Pada pemeriksaan penanda tumor dengan memakai NSE didapatkan hasil yang meningkat sebesar 205,1 (normal <17). Diagnostik dengan FNAB didapatkan dengan malignant neuroendocrine tumor.

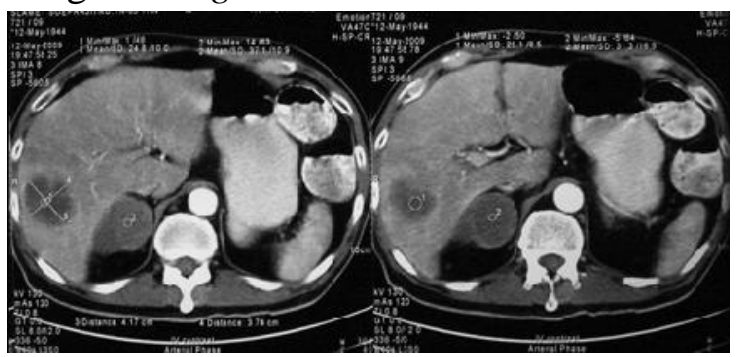

Gambar 1. Hasil CT-scan abdomen menunjukkan gambaran masa tumor suprarenalis kanan dengan metastase hepar.

\section{Kasus 2}

Penderita laki-laki 63 tahun, pertama kali periksa ke poliklinik bedah pada tanggal 19 Maret 2010 dengan keluhan nyeri abdomen disertai massa di abdomen kiri atas. Defekasi tidak ada gangguan, tidak ada mual dan muntah, tidak ikterus, dan berat badan stabil $59 \mathrm{~kg}$. Riwayat operasi nefrektomi kanan oleh karena Grawitz tumor pada tahun 1994.

Pada pemeriksaan fisik abdomen hanya didapatkan massa abdomen kiri atas dan nyeri tekan. Dari pemeriksaan USG abdomen didapatkan gambaran massa pada kauda pankreas (gambar 2). Sedangkan pada pemeriksaan dengan MRI didapatkan gambaran massa tumor di paraaorta kiri dengan ukuran 76x76x70 mm (gambar 3). Rontgen thoraks menunjukkan adanya proses konsolidasi di paru-paru kiri (metastase paru). Penanda tumor NSE menunjukkan adanya peningkatan yaitu 30,9. Penegakan diagnosis dengan FNAB guiding CT mendapatkan hasil berupa karsinoma neuroendokrin. Penderita menolak tindakan.

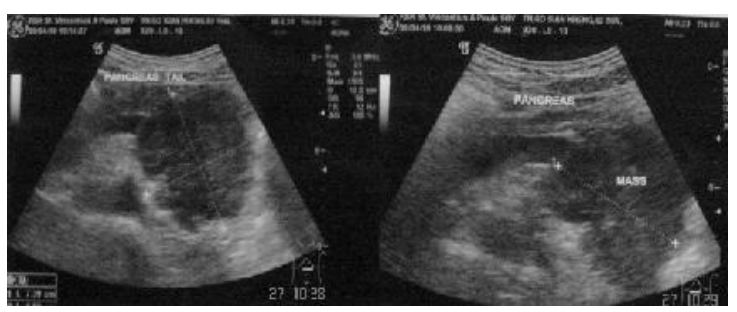

Gambar 2. Hasil pemeriksaan USG menunjukkan gambaran masa di kauda pankreas.

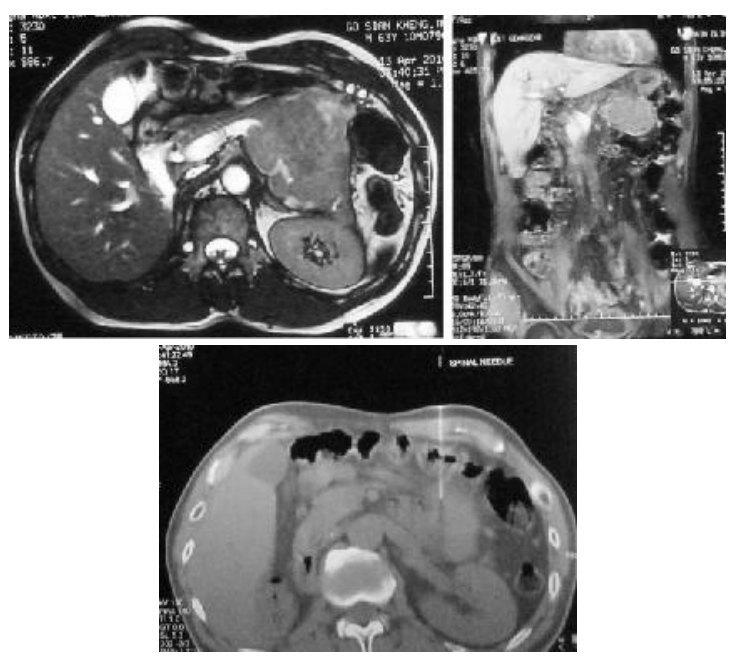

Gambar 3. Hasil pemeriksaan MRI menunjukkan adanya gambaran massa di paraaorta kiri berukuran 
76x76x70 mm dan hasil pemeriksaan FNAB guiding CT mendapatkan suatu gambaran karsinoma neuroendokrin.

\section{Kasus 3}

Penderita perempuan 68 tahun dengan keluhan nyeri abdomen kiri sejak satu bulan, tidak ada keluhan mengenai defekasinya. Pada pemeriksaan abdomen didapatkan massa di daerah abdomen kiri atas, teraba padat keras, dengan ukuran lebih kurang $15 \times 15 \times 15 \mathrm{~cm}$. Pada pemeriksaan USG didapatkan gambaran massa diabdomen kiri dengan diferensial diagnosis suatu massa lien. Dari pemeriksaan MSCT abdomen didapatkan gambaran massa tumor di kauda pankreas berukuran $15,4 \times 20,3 \mathrm{~cm}$, massa tumor sudah menginfiltrasi lien, dan melingkari aorta (gambar 4). Pada pemeriksaan penanda tumor dengan NSE didapatkan nilainya menigkat yaitu 218,40 (normal<17). Pada pemeriksaan FNAB didapatkan suatu gambaran tumor neuroendokrin.

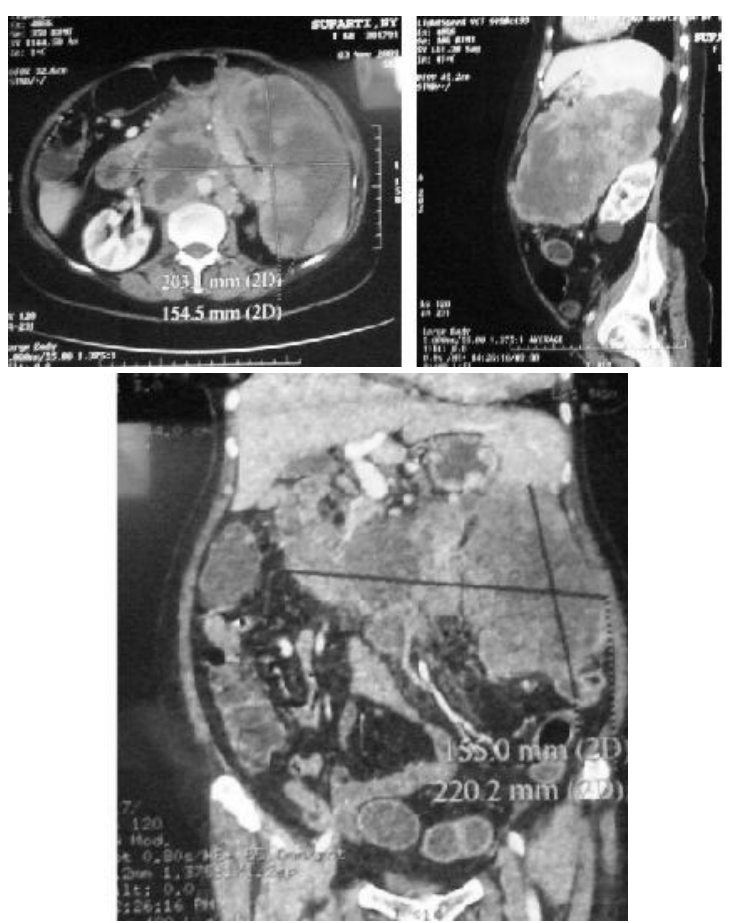

Gambar 4. Hasil MSCT menunjukkan gambaran massa ukuran 15,5x22,02 $\mathrm{cm}$ yang tumbuh melingkari aorta dan sudah menginfiltrasi lien.

\section{Kasus 4}

Perempuan 60 tahun dengan keluhan nyeri abdomen. Pada pemeriksaan fisik tidak didapatkan adanya kelainan. Pada pemeriksaan USG abdomen didapatkan gambaran simple cyst berukuran 9x6 cm di daerah kaput pankreas (gambar 5). Korpus dan tail pankreas normal. Dari pemeriksaan MSCT abdomen didapatkan gambaran massa soliter dengan ukuran $11 \times 9 \mathrm{~cm}$, lokasi massa menempel pada sisi inferior kaput dan korpus pankreas (gambar 6). Penanda tumor NSE menunjukkan peningkatan 56,3 (normal <17). Penegakan diagnosis melalui FNAB mendapatkan suatu gambaran tumor neuroendokrin.

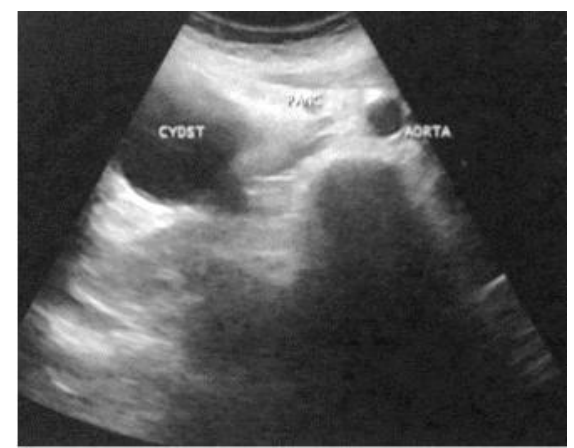

Gambar 5. Hasil pemeriksaan USG menunjukkan gambaran simple cyst ukuran 9x6 $\mathrm{cm}$ di daerah kaput pankreas.
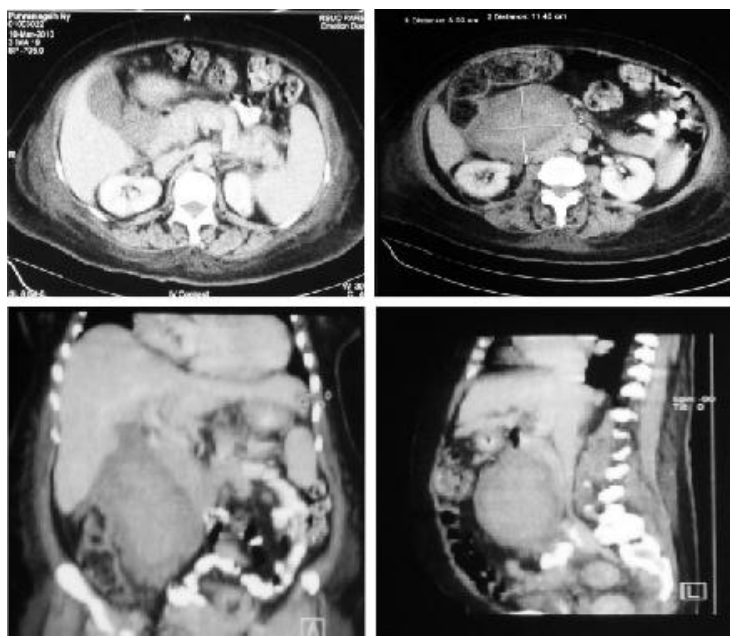

Gambar 6. Hasil

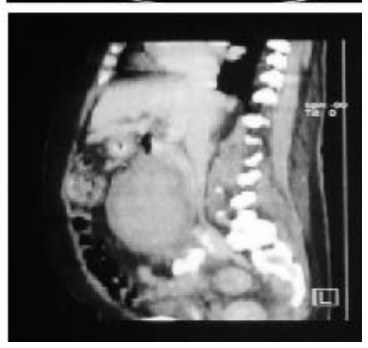

pemeriksaan MSCT menunjukkan adanya gambaran massa kistik bersepta dengan dinding tebal (encapsulated) dengan ukuran 11x9 cm, kesan fixed, melekat pada sisi inferior kaput dan korpus pankreas. 


\section{Kasus 5}

Perempuan 65 tahun datang ke bagian bedah untuk memeriksakan diri pada bulan Nopember 2008 dengan keluhan berupa kesulitan defekasi disertai timbul benjolan di daerah os sakrum. Pada pemeriksaan RT teraba masa diluar lumen rektum dengan konsistensi padat, keras dan terfiksir. Pada penderita ini dilakukan pemeriksaan CT kolonografi dengan hasil berupa normal kolon dan terdapat metastase di hepar. Dari pemeriksaan MRI didapatkan masa tumor pre-sakral dengan metastase hepar. Pemeriksaan penanda tumor NSE didapatkan meningkat sampai 46,45 (normal <17). Pemeriksaan FNAB guiding CT didapatkan hasil berupa suatu malignant neuroendocrine tumor (gambar 7).

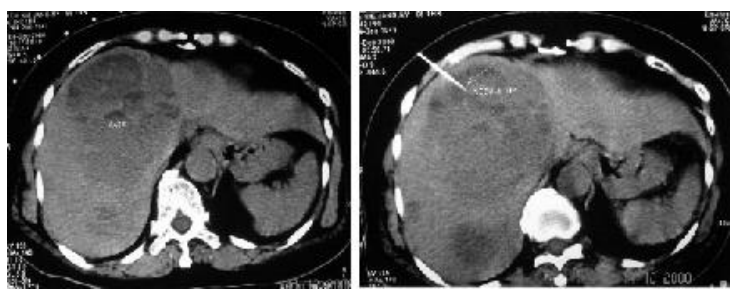

Gambar 7. FNAB guiding CT.

Pada bulan Desember 2008 dilakukan tindakan biopsi terhadap benjolan di daerah sakrum dan didapatkan hasil PA berupa suatu metastase karsinoma neuroendokrin. Di bulan yang sama penderita mengeluh tidak bisa lagi defekasi oleh karena terjadi obstruksi akibat pendesakan tumor ke daerah rektum (gambar 8) sehingga dilakukan tindakan kolostomi tranversum kiri. Pada bulan Januari 2009 penderita masuk rumah sakit untuk dilakukan tindakan operasi terhadap tumor primernya. Saat itu dilakukan tindakan eksisi luas S3-4 in toto dengan tumor pre-sakral dilanjutkan dengan reseksi abdomino-perineal (gambar 9-12). Hasil PA paska operasi didapatkan suatu karsinoma neuroendokrin yang sudah menginfiltrasi sakrum dan perirektal, didapatkan juga metastasis KGB positif 2 buah dengan invasi perinodal. Setelah 2 minggu perawatan penderita rawat jalan. Pada follow up penderita didapatkan kondisi membaik pada awal kontrol, fungsi kolostomi baik dan terjadi peningkatan berat badan dari $58 \mathrm{~kg}$ menjadi $59 \mathrm{~kg}$. Selama 2 tahun paska operasi penderita kontrol sebanyak 6 kali dan dari hasil kontrol USG didapatkan nodul hepar bertambah banyak. Pada akhirnya penderita meninggal pada bulan November 2010.

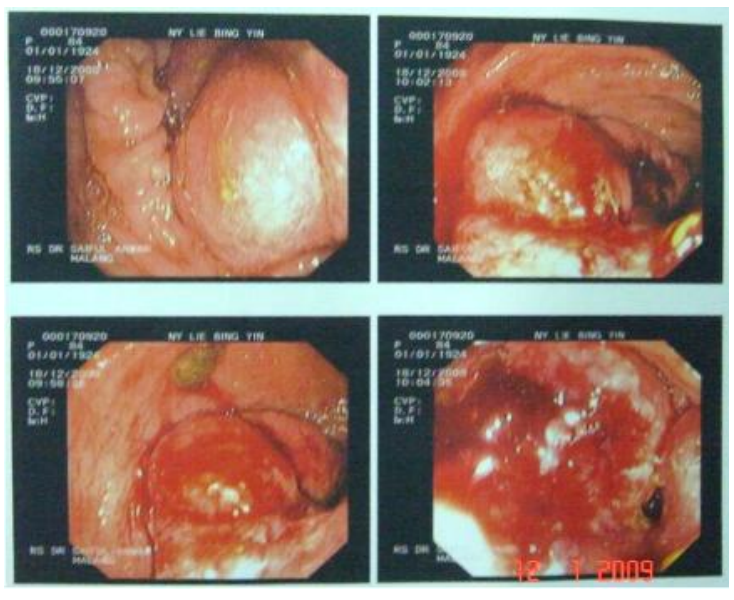

Gambar 8. Gambaran hasil kolonoskopi menunjukkan adanya massa tumor rektum yang merupakan infiltrasi tumor dari luar lumen.

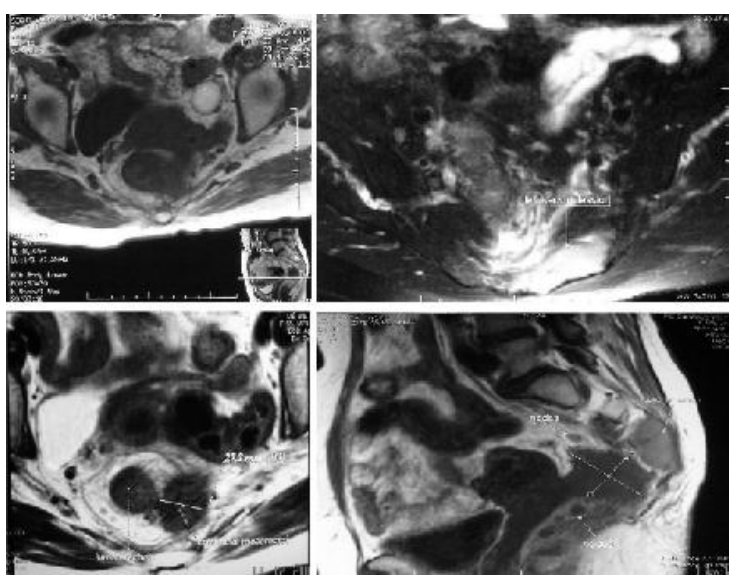

Gambar 9. Gambaran MRI menunjukkan massa tumor pre-sakral ukuran 47,1x30,3mm yang sudah menginfiltrasi sakrum dan mesorektal. Tampak juga pembesaran KGB perirektal. 


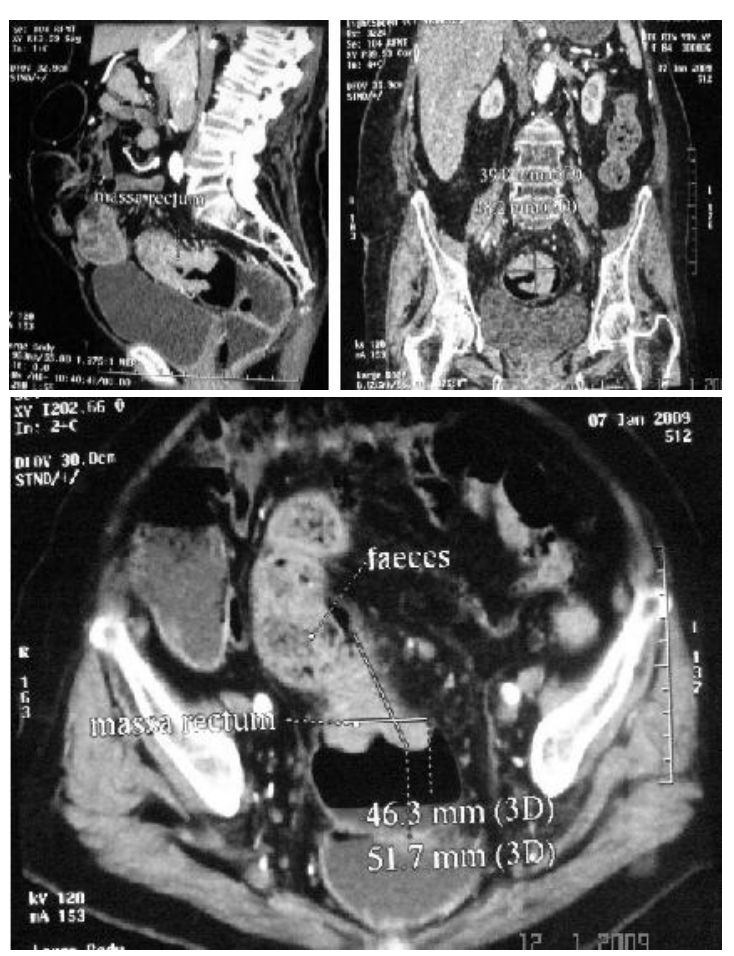

Gambar 10. Hasil CT-kolonografi yang menunjukkan adanya masa tumor di rektum pada irisan sagital, koronal, dan aksial.

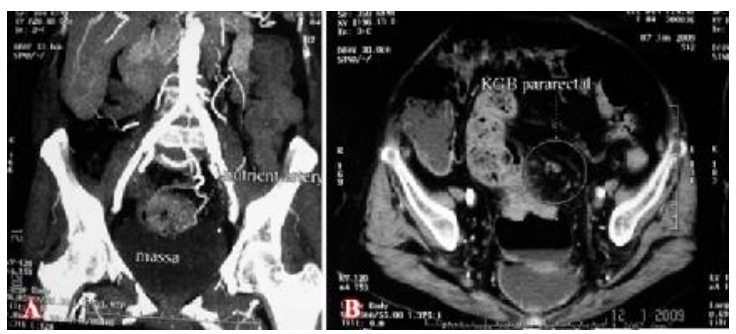

Gambar 11. Hasil CT-kolonografi yang menunjukkan gambaran artery nutrient tumor (A) dan adanya gambaran pembesaran KGB pararektal (B).

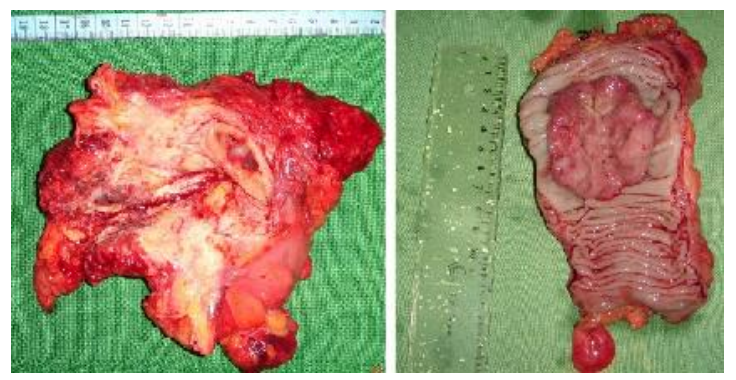

Gambar 13. Gambaran makros tumor pre-sakral dengan infiltrasi ke rektum.

\section{DISKUSI}

Angka insiden NETs telah meningkat menjadi 40 sampai 50 kasus per juta per tahun, mungkin karena diagnosis yang lebih baik dan ketersediaan cara yang sangat spesifik dan sensitif untuk mengukur produk tumor ini, "imunohistokimia", dan peningkatan teknik untuk deteksi tumor. Dengan demikian, kenaikan yang dirasakan dalam insiden mungkin bukan perubahan nyata dari insiden penyakit ini. ${ }^{11}$

Di Amerika Serikat, insiden NETs didapatkan sekitar 2 kasus per 100.000 penduduk dan sekitar $0,5 \%$ dari seluruh keganasan. Di Jepang pada tahun 2005 pernah dilakukan penelitian epidemiologi tentang tumor ini dan mendapatkan insiden PETs sekitar 1,01 per 100.000 dan insiden GI-NETs sebesar 2.10 per 100.000. Di Indonesia, belum didapatkan data yang akurat mengenai tumor ini. ${ }^{10}$ Di RSUD Dr. Soetomo ini hanya didapatkan 5 kasus dalam kurun waktu 2 tahun. Pada sebagian besar tumor-tumor neuroendokrin, gejala yang muncul hanya merupakan konsekuensi dari pertumbuhan tumor itu sendiri. Dengan lebih dari 100.000 kasus, NETs mempunyai angka prevalensi lebih tinggi dibandingkan dengan kanker lambung dan pankreas. ${ }^{12}$

Sebagian besar NETs terjadi pada saluran cerna $(67,5 \%)$ dan pada sistem pernafasan $(25,3 \%)$. Pada saluran cerna, kebanyakan NETs didapatkan pada usus halus $(41,8 \%)$, rektum $(27,4 \%)$ dan lambung (8,7\%). Data dari The Suveveillence Epidemiology and End Results (SEER) dan The National Cancer Institute menunjukkan bahwa terjadi peningkatan yang dramatis dari insiden NETs sejak 1973 sampai 2004. ${ }^{12}$

Tumor neuroendokrin jarang ditemukan pada anak-anak dan sering terjadi pada penderita dengan usia lebih dari 50 tahun. Angka kejadian dua kali lebih banyak pada laki-laki dibandingkan perempuan. ${ }^{7-9}$ Dari 5 kasus yang kami dapatkan di RSUD Dr. 
Soetomo rata-rata mempunyai rentang umur dari 60-68 tahun yang terdiri dari 2 laki-laki dan 3 perempuan.

Terdapat banyak tipe dari NETs dan tumor ini dapat ditemukan di seluruh tubuh. Hampir sebagian besar dari NETs didapatkan pada saluran cerna dan kelompok tumor ini dikenal sebagai gastroenteropancreatic neuroendocrine tumors (GP-NET), yang meliputi carcinoid tumor dan pancreatic neuroendocrine tumors ( $\mathrm{pNET}$ ).

NETs dapat diklasifikasikan menurut beberapa cara yaitu berdasarkan histologi, ekstensi tumor, dan tempat asalnya. ${ }^{13-16}$ Klasifikasi NETs berdasarkan histologi. Saat ini, tidak ada sistem penilaian yang seragam yang diakui untuk malignant NETs, terutama karena data untuk mendukung sistem ini belum ada. Konsensus antara para pakar saat ini di lapangan adalah bahwa NETS dapat secara mendasar dibagi antara 2 kelas patologis klinis yang berbeda yaitu well dan poorly differentiated NETs. Well-differentiated NETs dapat diklasifikasikan sebagai low atau intermediate grade, tergantung pada kriteria yang diterapkan dari salah satu sistem grading multipel yang digunakan untuk NETs. Poorly-differentiated NETs adalah high-grade carcinomas ditandai dengan penyebaran yang cepat, tahan terhadap pengobatan. ${ }^{13-16}$

Klasifikasi NETs berdasarkan ekstensi tumornya, yaitu local disease (satu fokus terisolasi dari NETs primer di usus halus), regional disease (NETs primer di usus halus dengan penyebaran mesenterik), distant disease (NETs primer di usus halus dengan penyebaran mesenterik dan metastasis hepar). ${ }^{13-16}$

Klasifikasi NETs berdasarkan tempat asalnya, yaitu pancreatic NETs (gastrinoma, insulinoma, VIPoma, sematostatinoma, dan polipetidoma pankreatik) dan other NETs (foregut: paruparu, lambung, dan duodenum bagian pertama), midgut (duodenum bagian kedua, jejunum, ileum, dan kolon asenden), dan hindgut (kolon transversum, desenden, sigmoid, dan rektum). ${ }^{13-16}$

World Health Organization telah mengeluarkan klasifikasi yang didasarkan atas histopatologi dan karakteristik biologi antara lain grading sel tumor, ukuran dan lokasi tumor primer, proliferasi marker sel tumor, invasi lokal dan vaskuler, dan produksi substansi biologi aktif. Klasifikasinya adalah well differentiated endocrine tumors (low grade malignancy), well differentiated endocrine carcinoma (lebih agresif oleh karena adanya metastase), poorly differentiated endocrine carcinoma (high grade of malignancy dan prognosis buruk), dan mixed exocrineendocrine tumor. ${ }^{14,16}$

Dari 5 kasus yang kami dapatkan, bila ditinjau dari asal maka, 2 kasus dari pankreas, 1 kasus dari supra renalis, 1 kasus dari para aorta kiri, dan 1 kasus dari pre-sakral. Dari hasil pemeriksaan FNA semuanya mendapatkan menunjukkan suatu malignant neuroendocrine tumor, pada pemeriksaan sitologi ini tidak dapat menentukan gradingnya, sehingga klasifikasi NETs ini tidak bisa ditentukan.

Sering didapatkan NET tidak terdiagnosis. Pasien dengan NET kadangkadang tidak menimbulkan gejala dan tipe tumornya kemungkinan non-functioning. Banyak NET yang asimptomatik tersebut ditemukan secara kebetulan saat operasi untuk kondisi yang lainnya dan NETs dapat berupa tumor jinak atau ganas (cancerous). Jika NETs bersifat ganas maka tumor tersebut akan sangat berpotensial untuk bermetastase, walaupun tumornya sendiri pertumbuhannya sangat 
lambat. Data menunjukkan bahwa hampir sekitar 22\% NETs noncarcinoid fungsional didapatkan dengan metastase jauh saat diagnosis ditegakkan, sedangkan tumor carcinoid yang muncul disertai proses metastase sebesar 19\%. Jika didapatkan metastase jauh saat pertama kali NETs terdiagnosis, angka harapan hidup jangka 5 tahunnya diperkirakan sekitar $27 \%$ pada pasien tanpa pengobatan. Lebih dari $75 \%$ pasien dengan NETs didapatkan dengan metastasis hepar saat diagnosis ditegakkan. $^{2}$

Pada laporan kasus ini, kami dapatkan bahwa dari 5 kasus NETs yang didapat, 2 pasien NETs sudah didapatkan dengan metastase di hepar dan 1 kasus dengan metastase di paru-paru. Dari 2 kasus dengan metastase di hepar, hanya 1 pasien yang dapat diikuti perkembangannya, dan hanya bertahan 2 tahun sejak diagnosis NETs ditegakkan.

Sekitar $10 \%$ pasien-pasien dengan NETs akan menimbulkan sindroma karsinoid yang disebabkan oleh adanya produksi berlebihan dari serotonin atau hormon lainnya yang disekresi oleh beberapa NETs, sering timbul setelah kanker menyebar ke bagian tubuh lainnya. Gejala yang umum terjadi adalah diare, hot red flushing dari wajah dan serangan asma. Tumor yang non fungsional dapat menimbulkan gejala seperti nyeri abdomen (68-78\%), penurunan berat badan (32$50 \%)$, jaundice oleh karena obstruksi bilier atau metastasis (21-50\%), atau mual dan muntah $(36 \%){ }^{2}$

Survey oleh Claxton $W$ dan Poon D dari Carcinoid and Neuroendocrine Society of Singapore (CNETS) pada bulan Oktober 2010 tentang tumor neuroendocrine mendapatkan data dari 64 pasien dengan gejala yang umum muncul pada pasien NETs adalah 21 pasien dengan keluhan nyeri perut, 19 pasien flusing, 11 pasien diare, 6 pasien penurunan berat badan yang parah, dan 4 pasien muntah. Dari 5 kasus NETs yang kami laporkan didapatkan gejala nyeri abdomen sebanyak 3 pasien, kesulitan defekasi 1 pasien, dan 1 pasien tanpa gejala yang khas. ${ }^{15}$

Pemeriksaan penanda tumor terhadap kelima kasus NETs dilakukan dengan memakai penanda tumor neuron spesific enolase (NSE). Dari hasil permeriksaan ini didapatkan peningkatan nilai NSE pada semua kasus, yaitu berkisar 30,9 sampai 218,40, dimana nilai normalnya adalah kurang dari 16,3.

Dalam kepustakaan dikatakan bahwa terdapat berbagai penanda tumor, termasuk NSE dan chromogranin A (CGA) yang telah dievaluasi sebagai alat untuk mendeteksi NETS dan sebagai indikator perkembangan tumor dan respon terhadap terapi. Neuron spesifik enolase mempunyai sensitivitas bervariasi (43-100\%) dan spesifisitas rendah (65\%) sebagai penanda serum untuk NETs. Peningkatan kadar sirkulasi CGA ditemukan pada sekitar 60$80 \%$ pada NETs, baik yang fungsional dan tidak fungsional, bahkan pada kasus nonneoplastik, seperti insufisiensi ginjal, gastritis atrofi kronis, terapi dengan penghambat pompa proton dapat memberikan hasil positif palsu, hal ini akan mengurangi nilai spesifitasnya.,

Imaging memiliki peran penting dalam lokalisasi tumor primer, mengidentifikasi lokasi metastasis dan menilai respon terhadap perawatan. Pada serial kasus ini pencitraan awal dilakukan untuk mengetahui lokasi tumor dan menilai resektabilitas tumor tersebut. Dimulai dari pemeriksaan USG, CT-scan, dan MRI. Dari kelima kasus NETs yang dikumpulkan, didapatkan 2 pasien dengan kondisi tumor yang non-resectable. Satu 
kasus dengan tumor kauda pankreas dari pemeriksaan USG, ternyata setelah dilakukan pemeriksaan MRI didapatkan tumor di para aorta kiri, satu kasus dengan pemeriksaan CT-scan didapatkan masa tumor pada kauda pankreas yang sudah menginfiltrasi lien dan melingkari aorta.

Untuk tumor karsinoid dan pankreas, CT dan MRI sangat baik dalam menentukan sejauh mana metastasis dan menilai respon terhadap perawatan. Kedua teknik tampaknya memiliki kepekaan yang sama untuk mendeteksi tumor ini, mulai dari 30\% menjadi 94\%. Endoskopi USG memiliki peran penting dalam penilaian pra operasi dari pankreas dimana kemungkinan terdapat small functioning tumor atau kecurigaan adanya multipel tumor. Teknik ini sangat berhasil di tangan ahli, dengan sensitivitas setinggi 79-100\%. 2,4

Modalitas pencitraan fungsional, seperti skintigrafi reseptor somatostatin (SRS, Octreoscan (), memiliki dampak besar pada manajemen pasien dengan menyediakan alat untuk staging tumor yang lebih baik, visualisasi terhadap occult tumor, dan evaluasi kelayakan untuk pengobatan dengan analog somatostatin (SSA). Bahkan pada NETs yang umumnya mengekspresikan reseptor somatostatin dan dengan pemberian SSA radiolabelled, tumor dapat dicari dengan pemeriksaan skintigrafi. SRS adalah pemeriksaan yang sangat khusus dengan sensitivitas untuk tumor lebih dari $1 \mathrm{~cm}$ kurang lebih $80 \%$ 90\% (dengan pengecualian insulinoma yang mengekspresikan reseptor somatostatin hanya 50\% dari kasus). SRS juga mendeteksi metastasis jauh dengan sensitivitas yang dapat mencapai $96 \% .^{2,4}$.

Jika memungkinkan, operasi radikal adalah merupakan terapi standar untuk NETs. Jika ada locoregional atau metastasis hepar, operasi debulking dapat dilakukan pada pasien dengan kemungkinan tumor bisa diangkat hampir 90\%. Disarankan untuk melakukan operasi paliatif dalam situasi klinis berikut, 2,5,16,17 yaitu pada tumor primer dengan metastasis hepar yang non-operabel (terutama pada NET fungsional) karena gejala berkorelasi dengan massa neoplastik; jika tumor primer terlokalisir di usus kecil, karena dapat mengakibatkan obstruksi usus; dan dalam kasus operasi dimana memungkinkan pengobatan multimodal berikutnya.

Kombinasi beberapa terapi dapat dilakukan untuk metastasis hepar, seperti reseksi bedah, (kemo) embolisasi, ablasi radiofrekuensi dan, dalam kasus-kasus tertentu dapat dipertimbangkan untuk dilakukan transplantasi hepar orthotopic. Meskipun ada beberapa studi yang membandingkan pilihan pengobatan yang berbeda pada metastasis hepar, akan terlihat bahwa perlakuan yang berbeda meningkatkan ketahanan hidup pada 5 tahun secara umum dari $30 \%$ untuk tumor yang tidak bisa ditangani sampai 50$70 \% .^{16,17}$

Terapi medis dari NETs adalah berbeda tergantung dari apakah NETs tersebut well differentiated atau poorly differentiated. Neuroendokrin tumors fungsional biasanya adalah well differentiated dan target utama terapi berupa pengontrolan gejala. Tumor ini umumnya lambat dalam pertumbuhan, dengan harapan hidup yang relatif lama, maka penting untuk memastikan pasien dengan kualitas hidup yang baik. ${ }^{16-18}$

Poorly differentiated NETs memiliki indeks proliferasi tinggi dan bisa diobati dengan kemoterapi, meskipun belum ada kombinasi regimen standar. Etoposid cisplatin plus dan streptozotocin dalam kombinasi dengan 5-fluorouracil dan 
doxorubicin sering digunakan. Kemoterapi kombinasi baru dengan doxorubicin, 5fluorouracil, dan dacarbazine telah menunjukkan aktivitasnya dalam pengobatan NETs. ${ }^{16-18}$

Sementara well differentiated NETs tidak responsif terhadap kemoterapi (streptozotocin, doxorubicin, dacarbazine, dan 5-fluorouracil) dengan hanya sekitar $10 \%$ dari carcinoids memiliki respon positif, tingkat respons terbaik (40-70\%) telah dilaporkan dalam beberapa penelitian untuk kanker anaplastik, menggunakan regimen yang berbeda dengan cisplatin dan etoposid, meskipun tidak ada bukti cukup untuk dapat memperbaiki kualitas hidup. ${ }^{2,5,18}$

Pada pasien dengan well differentiated neuroendokrin tumor atau tipe carcinoids, yang menunjukkan indeks proliferasi rendah, maka bioterapi (analog somatostatin dan interferon- $\alpha$ ) adalah pengobatan pilihan, karena aktivitas biologis yang intensif dari tumor ini berkorelasi dengan sindrom karsinoid. ${ }^{18}$

Analog somatostatin (octreotide dan lanreotide), yang mengikat reseptor somatostatin diproduksi oleh sel tumor neuroendokrin, dianggap sebagai pengobatan lini pertama untuk low grade NETs, meskipun hubungan antara ekspresi somatostin reseptor dan respon klinis masih belum pasti. Aktivitas antitumor dari agen ini kemungkinan besar akan berkaitan dengan pengurangan faktor pertumbuhan tumor, seperti faktor pertumbuhan insulin (IGF-I), faktor pertumbuhan epidermis (EGF), dan pengurangan zat biologis aktif. Rata-rata, analog somatostatin mampu mencapai perubahan sindrom dan biokimia dalam $70 \%$ dan $30-50 \%$ pasien, tetapi mereka mempunyai respon obyektif yang sangat rendah $(10 \%) .{ }^{18-20}$ Penggunaan long-acting
(LAR) formulasi octreotide telah memberikan peningkatan yang signifikan dalam kepatuhan pasien dengan mengubah jadwal dari tiga administrasi subkutan setiap hari menjadi satu administrasi intramuskular setiap 28 hari. $^{16}$

Selain itu, interferon alfa, seperti monoterapi atau kombinasi dengan SSAs, dapat digunakan untuk menghambat hipersekresi hormon dan untuk menstabilkan penyakit, dengan tingkat respon yang bervariasi. Telah ada respon biokimia di $40-60 \%$ pasien, perbaikan gejala dalam $40-70 \%$ pasien, dan penyusutan tumor signifikan dalam ratarata $10-15 \%$ dari pasien. Interferon digunakan untuk indikasi yang sama seperti yang SSAs pada NETs dari usus, kecuali untuk krisis karsinoid. Efek samping umumnya ringan, sindroma seperti flu, kelelahan, penurunan berat badan, polineuropati, myositis, trombositopenia, anemia, leukopenia, dan hepatotoksisitas. ${ }^{16,18}$

Pengobatan gastrinomas didasarkan pada penggunaan inhibitor pompa proton pada dosis yang tepat (omeprazole dan lansoprazole 40-60 sampai $120 \mathrm{mg} /$ hari). Insulinomas dapat diterapi dengan diazoxide yang dikombinasi dengan hidroklorotiazida, jika terapi ini tidak efektif, channel blockers calcium, beta blocker, dan glukokortikoid dapat digunakan. Pada karsinom NE yang well differentiated terapi didasarkan pada penggunaan SSAs, interferon dan yang terbaru adalah targeting therapy. ${ }^{16,19,20}$

Terapi radiasi dapat digunakan untuk mengobati tumor GEP-NE. Terapi radiasi eksternal digunakan untuk membunuh sel tumor, kadang-kadang digunakan untuk meringankan gejala penyakit, dan terutama berguna pada pasien dengan metastase tulang. ${ }^{16,20}$ 


\section{SIMPULAN}

Tumor neuroendokrin adalah bentuk neoplasma yang jarang dan sering muncul dengan berbagai variasi klinis, dapat ditemukan pada seluruh tubuh, namun yang terbanyak adalah dari saluran cerna. Penegakan diagnosis jaringan dapat dilakukan dengan FNAB guiding USG (ultrasonografi) atau CT dan pemeriksaan penanda jaringan NSE. Penentuan resektabilitas tumor dapat dilakukan dengan pemeriksaan CT, MSCT (multislice computed tomography) atau MRI (magnetic resonance imaging. Kesulitan dalam hal tindakan dan mortalitas yang tinggi disebabkan karena hampir sebagian besar pasien datang dalam keadaan tumor yang sudah lanjut.

\section{DAFTAR PUSTAKA}

1. Aaron I, Eugene A, Richard R, et al. NANETS Consensus Guidelines for the Diagnosis of Neuroendocrine Tumor. Pancreas. 2010;39:713-4.

2. Mougey A, Adler D. Neuroendocrine Tumors: Review and Clinical Update. Hospital Physician. 2007;51:12-20.

3. Kaltsas G, Rockall A, Papadogias D, et al. Recent advances in radiological and radionuclide imaging and therapy of neuroendocrine tumours. Eur $J$ Endocrinol. 2004:151:15-27.

4. Massironi S, Sciola V, Peracchi M, et al. Neuroendocrine tumors of the gastro-entero-pancreatic system. World J Gastroenterol. 2008;14:5377-84.

5. Kaltsas G, Besser G, Grossman A. The Diagnosis and Medical Management of Advanced Neuroendocrine Tumors. Endocrine Review. 2004;25:458-511.

6. Warner RR. Enteroendocrine Tumors Other Than Carcinoid: A Review of Clinically Significant Advances. Gastroenterology. 2005;128:1668-84.
7. Vilar E, Salazar R, Pérez-García J, et al. Chemotherapy and role of the proliferation marker Ki-67 in digestive neuroendocrine tumors. Endocr-Relat Cancer. 2007;14:221-32.

8. Chung TP, Hunt SR. Carcinoid and Neuroendocrine Tumors of the Colon and Rectum. Clin Colon Rectal Surg. 2006;19:45-8.

9. Poston GJ, Jones LE. Carcinoid Tumors. Gastrointestinal Oncology Evidence and Analysis. 2007:317-336.

10. Ito $T$, Sasano $H$, Tanaka $M$, et al. Epidemiological study of gastroenteropancreatic neuroendocrine tumors in Japan. $J$ Gastroenterol. 2010;45:234-43.

11. Vinik AI, Woltering EA, Warner RR, et al. NANETS Consensus Guidelines for the Diagnosis of Neuroendocrine Tumor. Pancreas. 2010;39:714-34.

12. Yao JC, Hassan M, Phan A, et al. One hundreds years after "carcinoid" epidemiology of and prognostic factor for neuroendocrine tumors in 35,825 cases in the United State. J Clin Oncol. 2008;26:3063-72.

13. Klimstra DS, Modlin IR, Adsay NV, et al. Pathology reporting of neuroendocrine tumors: application of the Delphic consensus process to the development of a minimum pathology data set. Am J Surg Pathol. 2010;34:300-313.

14. Klöppel G, Perren A, Heitz PU. The gastroenteropancreatic neuroendocrine cell system and its tumors: the WHO classification. Ann $N$ Y Acad Sci. 2004;1014:13-27.

15. Claxton W, Poon D. Carcinoid and Neuroendocrine Society of Singapore (CNETS) Survey on Delay in Diagnosis of Neuroendocrine Tumors. Proceeding of 35th Congres of the 
European Society for Medical

Oncology; 2010 October 8-12; Milan, Italy; 2010.

16. Bajetta E, Catena L, Procopio G, et al. Is the new WHO classification of neuroendocrine tumours useful for selecting an appropriate treatment? Ann Oncol. 2005;16:1374-80.

17. Benali N, Ferjoux G, Puente E, et al. Somatostatin Receptors. Digestion. 2000;62:27-32.

18. De Vries H, Verschueren RCJ, Willemse PHB, et al. Diagnostic, surgical and medical aspect of the midgut carcinoids. Cancer Treat Rev. 2002;28:11-25.

19. Kulke MH. Neuroendocrine tumors: clinical presentation and management of localized disease. Cancer Treat Rev. 2003;29:363-70.

20. Kulke MH, Mayer RJ. Carcinoid tumors. N Engl J Med. 1999;340:85868. 